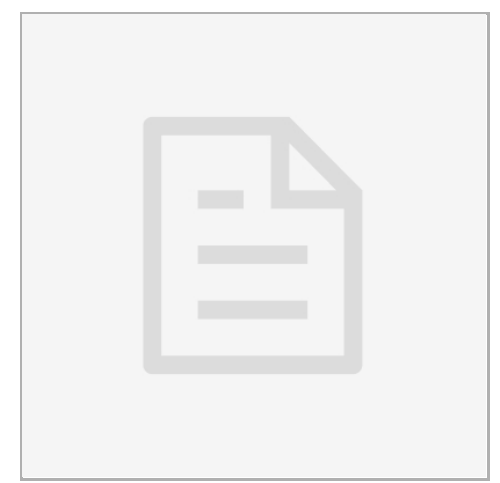

APR 23, 2020

\section{(3) When Misreporting the Value of Labor Benefits a Just}

\section{Cause}

J Jobu

Babin $^{1}$

${ }^{1}$ Western Illinois University

J Jobu Babin

Western Illinois University

\section{open ठaccess}

\section{DOI:}

dx.doi.org/10.17504/protocol s.io.bfhtjj6n

Document Citation: J Jobu Babin 2020. When

Misreporting the Value of Labor Benefits a Just Cause. protocols.io

https://dx.doi.org/10.17504/p rotocols.io.bfhtjj6n

License: This is an open access document distributed under the terms of the Creative Commons Attribution License, which permits unrestricted use, distribution, and reproduction in any medium, provided the original author and source are credited

Created: Apr 23, 2020

Last Modified: Apr 23, 2020

DOCUMENT integer ID:

36115

Anon Protocol Misreporting for Just Cause .pdf 